\title{
Peritoneostomy with latex coated polypropylene: experimental study in rats ${ }^{1}$
}

\section{Peritoniostomia com polipropileno revestido por látex: estudo experimental em ratos}

\author{
Renato Hugues Atique Claudio ${ }^{2}$, Augusto Diogo Filho ${ }^{3}$, Divino Oliveira Mamede Filho ${ }^{4}$ \\ 1. Study performed at Health Science, Faculty of Medicine Federal University of Uberlândia (UFU). Minas Gerais, Brazil. \\ 2. MD, Surgery Department, UFU, Minas Gerais, Brazil. \\ 3. PhD, Assistant Professor, Surgery Department, UFU, Minas Gerais, Brazil. \\ 4. Graduate Student, Faculty of Medicine, UFU, Minas Gerais, Brazil..
}

\begin{abstract}
Purpose: To evaluate if latex coated polypropylene mesh leads to less adhesions formation. Methods: 90 rats were distributed in three groups. Group I (control) was submitted to median laparotomy and posterior synthesis; Group II (polypropylene) was submitted to a segment resection of the abdominal wall, and the defect was corrected with a polypropylene mesh; Group III using the new material (latex coated polypropylene). After 45 days the euthanasia procedure was done and the adhesions were evaluated in 2 ways: 1) classification in a grading system; 2) evaluation of the adhesion area, which was calculated by resection of the adhesions after dying with Indian blue ink. Results: The classification in a grading system showed that Group III animals had less adhesions formation $(\mathrm{P}<0.05)$, but the evaluation of the adhesion area did not show any difference $(\mathrm{P}>0.05)$. The severe complications (fistula, evisceration and obstruction), which were lethal, were not reduced by the latex coated material. Conclusion: Latex coated polypropylene causes fewer adhesion formations than polypropylene alone, although it does not diminish the severe early complications.
\end{abstract}

Key words: Polypropylenes. Latex. Surgical Mesh.

\section{RESUMO}

Objetivo: Avaliar se o revestimento da tela de polipropileno com látex leva a menor formação de aderências. Métodos: Foram utilizados 90 ratos, distribuídos em três grupos de 30: grupo I (controle) animais submetidos a laparotomia mediana e posterior síntese; grupo II (polipropileno) ressecção de segmento da parede abdominal e síntese com tela de polipropileno; grupo III, (polipropileno revestido por látex). Eutanásia foi realizada após 45 dias e as aderências avaliadas sob duas formas: 1) classificação em graus; 2) avaliação da área aderida, calculada corando-se o segmento da parede contendo as aderências que posteriormente foram ressecadas produzindo uma região clara em contraste com o restante da peça, corada. Resultados: Na avaliação por meio de graus, o grupo III apresentou menor formação de aderências $(p<0,05)$, mas quanto a avaliação da área aderida não houve diferença $(\mathrm{p}>0,05)$. As complicações graves não foram reduzidas pelo revestimento por látex $(\mathrm{p}>0,05)$. Conclusão: O revestimento da tela de polipropileno por látex leva a menor formação de aderências, porém não diminui as complicações graves precoces.

Descritores: Polipropilenos. Latex. Telas Cirúrgicas.

\section{Introduction}

The major defects in the abdominal wall sometimes are difficult to repair and basically depend on three aspects, according to Rahal ${ }^{1}$ : 1) circumstances that impair cicatrisation, such as obesity, chronic pneumopathies, cirrhosis, malnutrition, prostatic obstruction, and others; 2) circumstances that hamper abdominal wall synthesis, due to abdominal hypertension, such as critical abdominal traumas and serious infections; 3) circumstances that facilitate dehiscence and evisceration, such as lack of strictness with asepsis and anti-sepsis, inappropriate incisions, inadequate hemostasis and under tension suture. Abdominal wall reconstruction must fulfill some rules, according to Di Bello and Moore ${ }^{2}$ : a) prevent visceral eventration; b) use materials that can incorporate with other tissues of the abdominal wall; c) provide a dynamic muscular support; d) allow a non tension repair and e) be permanent.
Based on these principles, the surgeon must employ appropriate surgical techniques to obtain a good result, using preferably anatomic structures appropriated to the region $^{3}$. In some cases there is no way to close the abdominal wall without using a supplementary material, but in spite of the various materials available, none of them can be considered ideal. Various studies have been performed aiming the improvement of the existing materials or the production and trial of better quality new materials. The most used prosthesis in our region is the polypropylene one, introduced by Usher ${ }^{4,5}$ in 1959 , a high-density polyethylene derived from ethylene gas. It differs from the conventional polyethylene in various aspects: a) a crystallized molecular structure which confers more resistance; b) it can be produced in a monofilament way; c) it has more chemical resistance and d) it tolerates high temperatures, what allows autoclave sterilization. In his preliminary study, Usher promptly demonstrated that 
polypropylene is incorporated by the neighbor tissues, does not fragment and does not lose its tension. Nowadays, the number of circumstances requiring peritoneostomy procedures has grown, such as critical peritonitis, the circumstances leading to abdominal wall loss and intraabdominal hypertension cases. There are various prosthesis ${ }^{6,7,8,9,10}$ but the most used is the polypropylene mesh that leads to adhesions formation ${ }^{11,12,13}$. Adhesion formation is part of a normal cicatrisation process and is observed in up to $100 \%$ of all surgical procedures in abdominal cavity ${ }^{14}$. In spite of being a slow process, the formation rate is determined in early post-surgical period ${ }^{15}$, so that preventing strategies will only be effective when used in trans and early post-surgical periods. In 1994, Coutinho $\mathrm{Neto}^{16}$, in experimental studies suggested the use of a latex biopolymer with the first aim of developing a prosthesis to partially reconstruct the esophagus. This material is extracted from Havea brasiliensis (rubber-tree). The product has already been experimentally used in dogs as an esophagus prosthesis ${ }^{16}$ and in humans for phlebopathic ulcer treatment ${ }^{17}$. However, this material has not yet been used in comparison with polypropylene prosthesis in abdominal wall reconstruction. The aim of this study is to determine if the biological behavior related to adhesions formation in abdominal wall reconstruction using latex coated propylene mesh is more adequate than the polypropylene mesh alone.

\section{Methods:}

We operated 90 adult mail rats, of the Wistar strain, apparently healthy, supplied by the Central Vivarium of The Faculty of Medicine of Ribeirão Preto - USP. The rats were acclimatized to the research environment 15 days before we started the experiment. The surgical and post-surgical procedures were performed in the Laboratory of Surgery Techniques of the Faculty of Medicine of Federal University of Uberlândia, where the animals received food and water ad libidum. The animals that died because of anesthesia problems, bleeding and accidents during the surgery were excluded. The animals were weighted and anesthetized by intramuscular injection of $30 \mathrm{mg} / \mathrm{Kg}$ of ketoamine hydrochloride and $0.5 \mathrm{mg} / \mathrm{Kg}$ of xylasine hydrochloride ${ }^{18}$. Afterwards they were submitted to abdominal trichotomy and anti-sepsis with $2 \%$ iodized polyvinylpirrolidone, with the placement of sterile zones. All the procedures were performed with sterilized material. The animals were randomly distributed in three groups:

Group I (control): the animals were submitted to a $4.0 \mathrm{~cm}$ medial laparotomy, without tissue resection. The cavity remained exposed to environmental air for 5 minutes. Synthesis was performed in a unique plan with a 4-0polyglactin thread in a continuous suture, and skin approximation was done with separated stitches with a 4-0 nylon. The dressing was done with gauze, sutured to the animal's skin with a 4-0 nylon.

Group II (polypropylene mesh): we did a resection of a fragment of the thickness of the whole abdominal wall, from skin to peritoneum, with an extension of $2.0 \mathrm{~cm} \mathrm{x} 3.0 \mathrm{~cm}$. For skin reconstruction we used a sterilized polypropylene mesh (Figure 1), of the same dimensions of the resection area, fixed with separated stitches with a 4-0-polyglactin thread. The dressing was made as described for group I.

Group III (latex coated polypropylene mesh): the same procedure described for group II, but with latex coated polypropylene prosthesis (Figure 1).

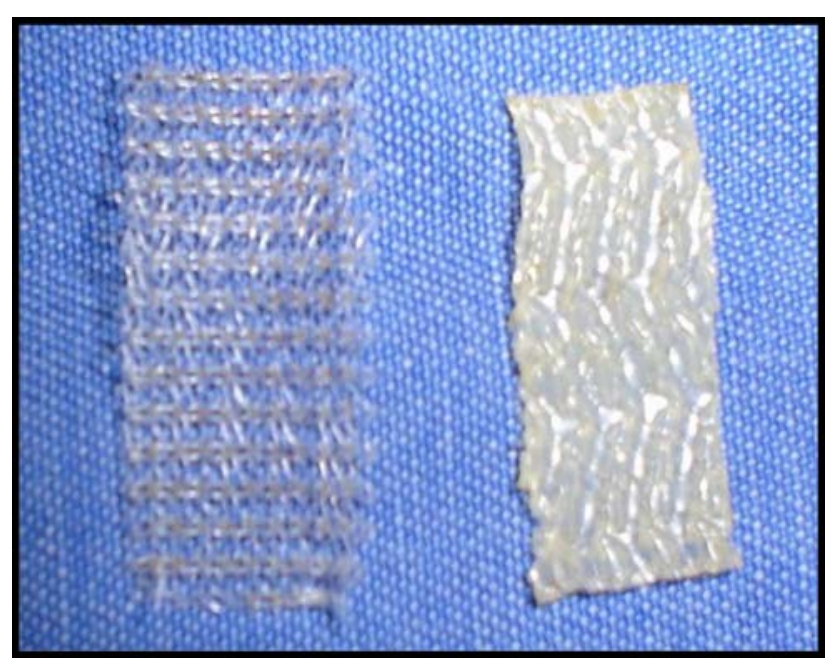

FIGURE 1 - Aspect of polypropylene (left) and latex coated propylene (right) prosthesis

Before this study we made a starting project using latex membranes as prostheses, but all the animals presented evisceration, what encouraged us to use latex coated polypropylene prosthesis. The surgeries were performed by three surgeons, in three different days, respecting the following conditions: a) on each day, an equal number of rats of each group was submitted to surgery; b) the order of surgery was drafted for each surgeon; c) rats of the same group were kept in the same cage. Forty-five days after surgery, all animals were weighted again and euthanasia was performed with high doses of anesthesia (ketoamine hydrochloride and xylasine hydrochloride). The animals that died before the day of euthanasia were submitted to necropsy to evaluate the cause of their death. The adhesions were evaluated under three independent aspects:

a) Classification proposed by D'Oliveira ${ }^{19}$, but with modifications ${ }^{20}$ :

GRADE 0: lack of adhesions.

GRADE 1: reduced number of adhesions, of fibrinous character, easily undone by manipulation.

GRADE 2: stable adhesions, between intestinal loops, not involving the abdominal wall, resistant to manipulation.

GRADE 3: stable adhesions, between the abdominal wall and an organ or a structure, resistant to manipulation.

GRADE 4: stable adhesions, between the abdominal wall and more than an organ or structure, resistant to manipulation.

GRADE 5: stable adhesions, between intestinal loops and the abdominal wall, with enteric fistulas, resistant to manipulation. 
b) Evaluation of the adhesion area demarcated by Indian blue, according to the method proposed by Dinsmore $^{12}$, with some adjustments: incision of the abdominal wall with an aerial margin of $1.0 \mathrm{~cm}$ from the scar, but at first only at superior and lateral (right and left) sides, aiming the evaluation of the adhesions.

After that, the section of the inferior portion of the abdominal wall was completed, including $1.0 \mathrm{~cm}$ of adhered structures (Figures 2 and 3). The peritoneal faces of the fragments were bathed in an Indian blue solution (Figure 4) and then exposed to the sun for about 30 minutes. When completely dry, the adhesions were resected (Figure 5) producing a light-colored non-stained area, contrasting with the rest of the piece, which remained stained (Figure 6). Photographs of all these tissues were taken using a conventional camera and an adjustable support placed at about $30.0 \mathrm{~cm}$ from the place where the pieces were. The euthanasia was performed on 3 different days, respecting the post-surgery time of 45 days. The material prepared in each day was photographed and only despised after photography development, to guarantee that the pictures had a good quality. The light-colored areas (corresponding to the adhesions areas) were calculated using the photographs and a planimeter (Digital planimeter\#330, GEBR HAFF GmbH D-87459 Germany), as visualized in Figure 7. This equipment functions with an apparatus where a weight stabilizes the system and is connected by a long arm to a control where the adjustments and the readings are made. This control is connected by a short arm to a magnifying glass with a central hole, which runs the contour of the area in the photograph that we want to measure. After calibration, the measures were made with the aid of a properly trained technician. To reduce reading mistakes, the device was programmed to measure each photo area 3 times, considering the mean as the final result. The statistical analyses were made with non-parametric tests (Mann-Withney) to evaluate the adhesions by grade, and parametric (Tukey) to adhesions weights and areas, where the level for rejection of the nullity hypothesis was fixed in 0.05 or $5 \%$.

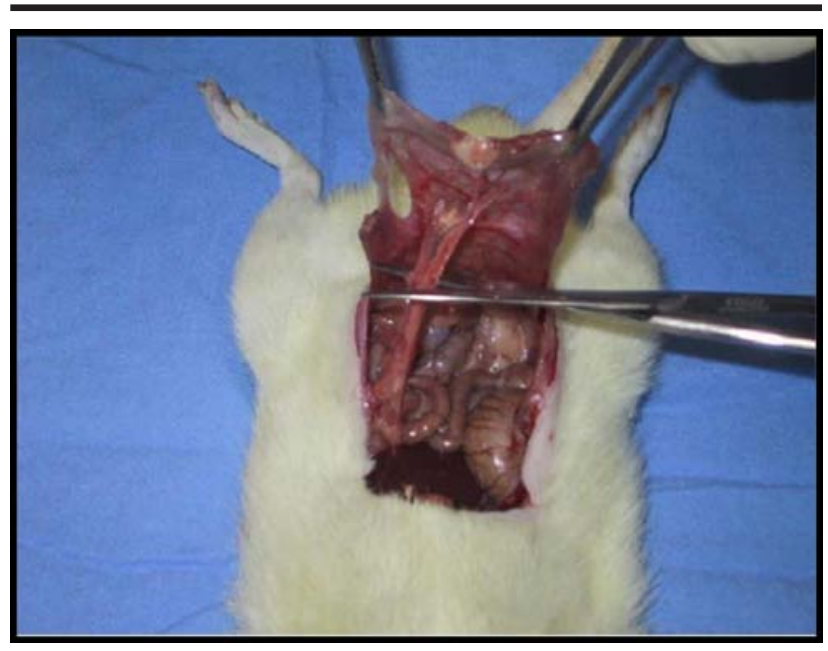

FIGURE 2 - Aspect of surgical wound after superior and lateral incisions, showing the adhesions between intestinal loops and parietal peritoneum, and the section site

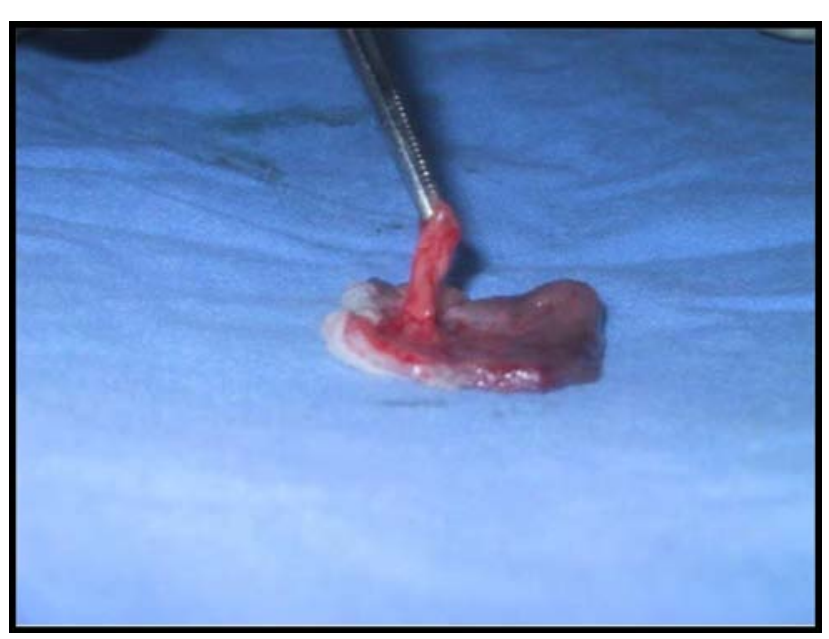

FIGURE 3 - Aspect of the resected abdominal wall, including $1.0 \mathrm{~cm}$ of adhesions, before dying



FIGURE 4 - Indian blue dying of peritoneal face of the resected abdominal wall fragment, including adhesions

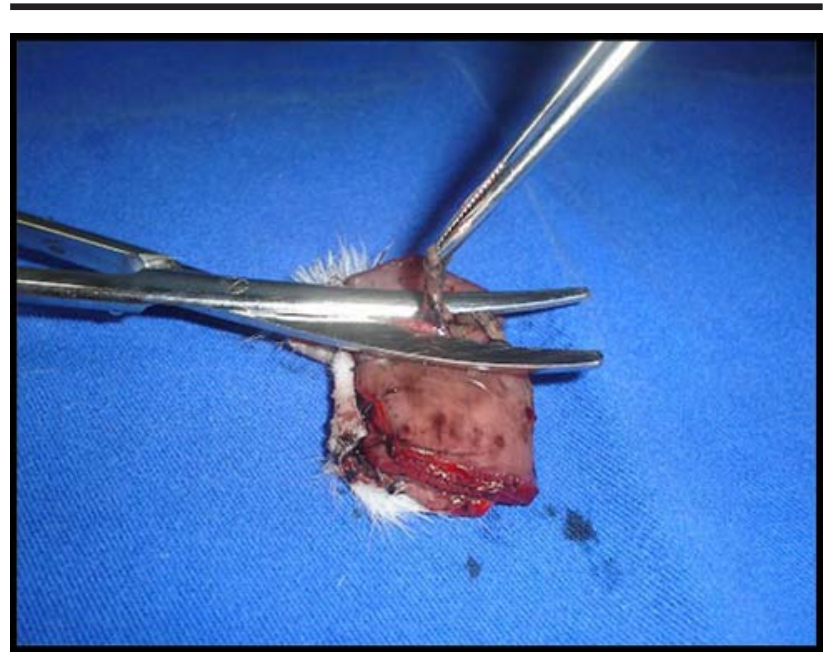

FIGURE 5 - Adhesions exeresis after Indian blue stain dying 


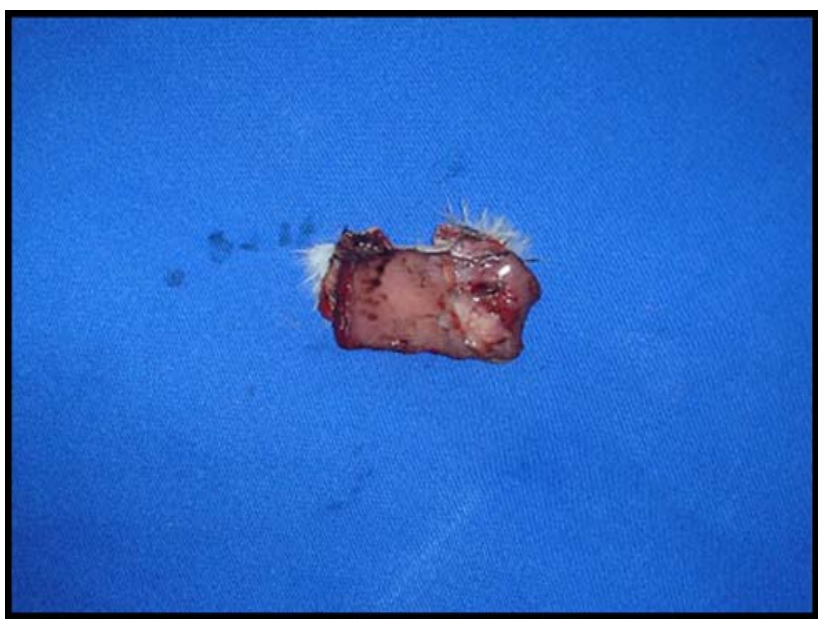

FIGURE 6 - Final aspect of the resected abdominal wall, showing the area of non-stained tissue, corresponding to the adhesion area

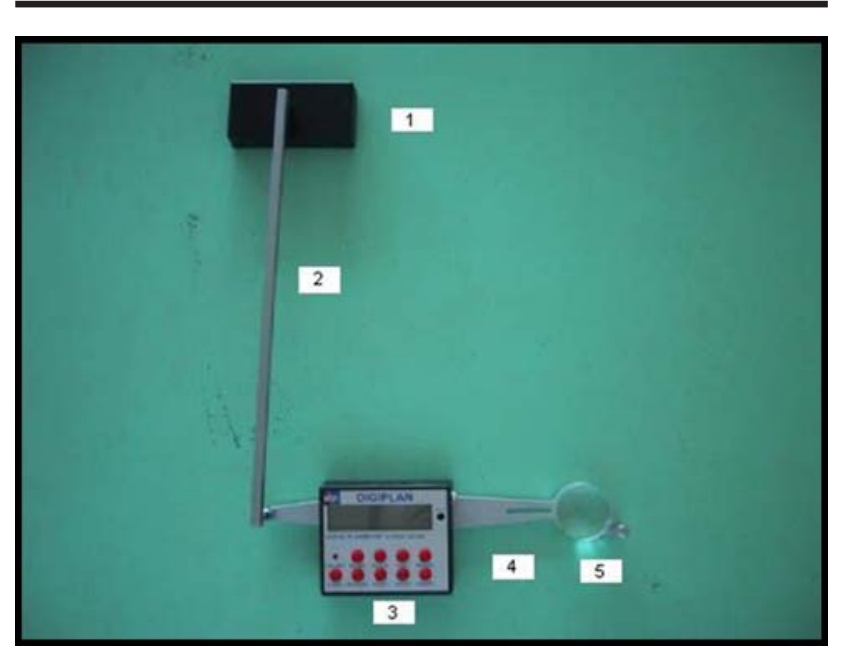

FIGURE 7 - A planimeter adjusted to calculate photo areas. 1. weight; 2. long arm; 3. control; 4. short arm; 5. magnifying glass

\section{Results}

Pre-surgery animals' weights and their distribution in groups are presented in Figure 8. The animals from groups I, II and III showed a weight mean of $340.16 \mathrm{~g}$ (standard deviation of $60.73 \mathrm{~g}$ ), $349.0 \mathrm{~g}$ (standard deviation of $50.45 \mathrm{~g}$ ) and $336.66 \mathrm{~g}$ (standard deviation of $38.73 \mathrm{~g}$ ) respectively $(p>0.05)$. In control group there were no complications or deaths. Of 30 animals from group II (polypropylene), eight died, one of them because of bleeding in early post-surgery, what leaded to its exclusion from the study. The other seven presented complications, as shown in Table 1. In group III (latex coated polypropylene), nine rats died before euthanasia, one due to anesthesia (excluded) and eight due to the complications listed in Table 1. The control group statistically presented fewer deaths than the other two groups $(\mathrm{p}<0.05)$, but there was no difference between polypropylene and latex coated polypropylene $(p<0.05)$. In relation to the animals' weight in euthanasia day, the following distribution was observed (Figure 9).
The control group animals' weights mean was $492 \mathrm{~g}$ (74.33g of standard deviation), polypropylene group $504 \mathrm{~g}$ (48.45g of standard deviation) and latex coated group $490 \mathrm{~g}$ (63.73g of standard deviation) ( $\mathrm{p}>0.05$ ). Peritoneal adhesions presented the following distribution, as visualized in Figure 10 and Table 2. The control group presented fewer adhesions when compared to the other two groups $(\mathrm{p}<0.05)$ and latex coated polypropylene group presented fewer adhesions formations $(\mathrm{p}<0.05)$ in relation to polypropylene group. The adhesion area was in mean $2.30 \mathrm{~mm}^{2}\left(9.35 \mathrm{~mm}^{2}\right.$ of standard deviation) in control group, $91.42 \mathrm{~mm}^{2}\left(44.77 \mathrm{~mm}^{2}\right.$ of standard deviation) in polypropylene group and $61.50 \mathrm{~mm}^{2}$ $\left(61.17 \mathrm{~mm}^{2}\right.$ of standard deviation) in latex coated polypropylene group. The control group presented smaller adhesions area in relation to the other two groups $(\mathrm{p}<0.05)$. There was no significant difference $(\mathrm{p}>0.05)$ between polypropylene and latex coated polypropylene groups. We should emphasize that two animals in control group and one in latex group, in spite of having been classified as having Level 1 adhesions, didn't have their area calculated because the adhesion area was so small that limited its calculation (Figure 11).

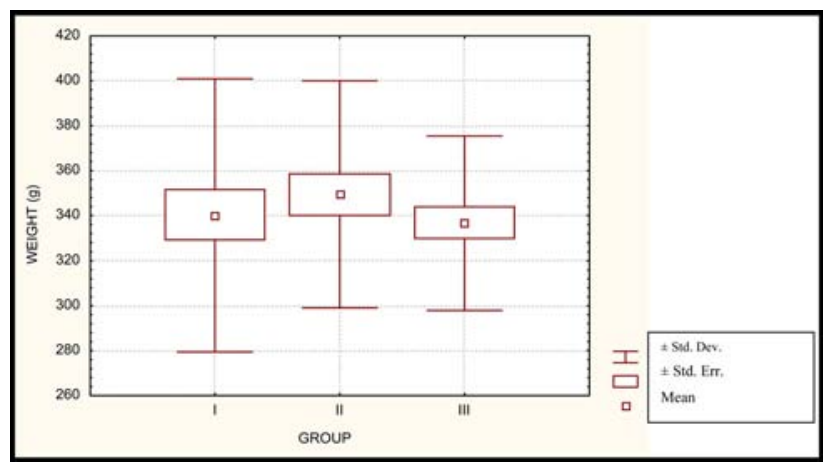

FIGURE 8 - Distribution of the animals by group, with maximum, minimum and medium weights in presurgery, and the standard deviation

TABLE 1 - The causes of deaths in group I and group II and the post-surgery days (PS)

\begin{tabular}{cccc}
\hline \multicolumn{2}{c}{ Group II } & \multicolumn{2}{c}{ Group III } \\
\hline Cause & Time & Cause & Time \\
\hline Enteric fistula & 7th PS & Enteric fistula & 6th PS \\
Enteric fistula & 9th PS & Enteric fistula & 9th PS \\
Enteric fistula & 14th PS & Enteric fistula & 9th PS \\
Enteric fistula & 19th PS & Enteric fistula & 10th PS \\
Enteric fistula & 19th PS & Obstruction & 16th PS \\
Obstruction & 9th PS & Obstruction & 17th PS \\
Evisceration & 31st PS & Evisceration & 1st PS \\
Bleeding & IPS & Evisceration & 10th PS \\
& & Anesthesia & IPS \\
\hline
\end{tabular}

8

9

Group I - control (no deaths); Group II- polypropylene; Group III(latex coated polypropylene); IPS= immediately post-surgery. 


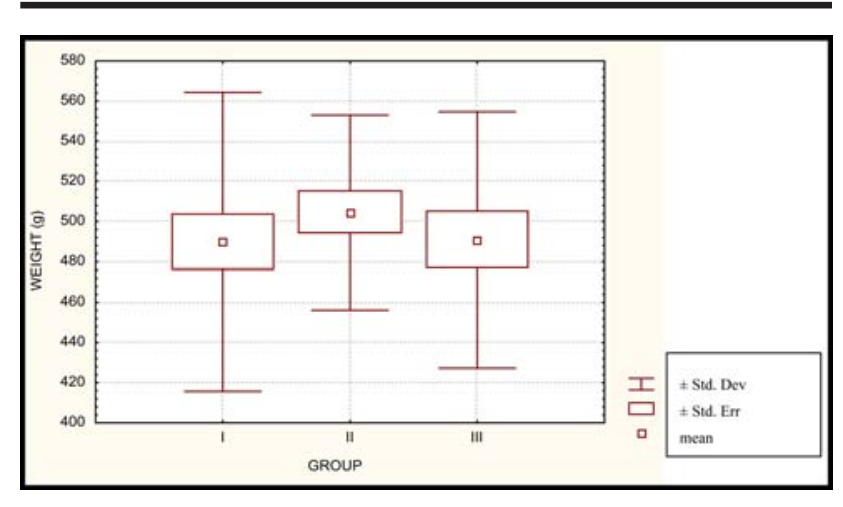

FIGURE 9 - Animals' weights on euthanasia day, distributed in groups. I. control; II. polypropylene; III. latex coated polypropylene

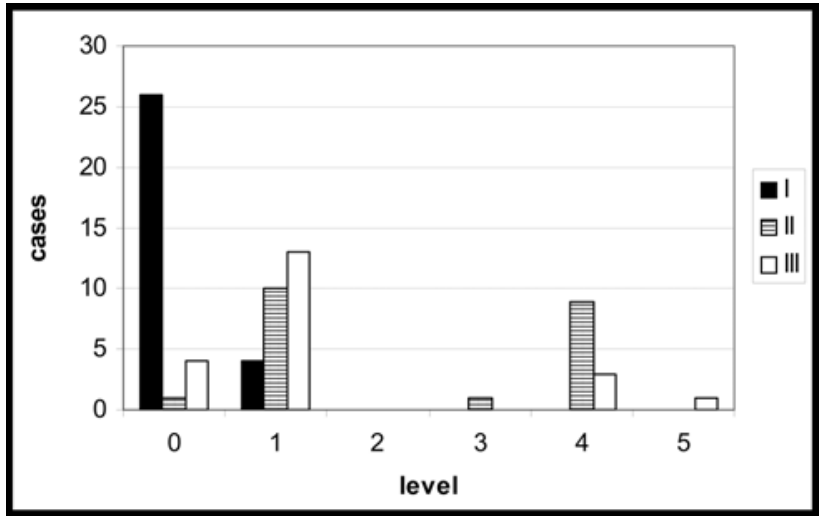

FIGURE 10 - Animals distribution in relation to the adhesion level, according to the studied group. I. control; II. polypropylene; III. latex coated polypropylene

TABLE 2 - Animals distribution in relation to the adhesions level according to the group, excluding the deaths before euthanasia

\begin{tabular}{ccccccccc}
\hline & \multicolumn{7}{c}{ Level } & \multicolumn{1}{c}{ Total } \\
\cline { 2 - 6 } Group & $\mathbf{0}$ & $\mathbf{1}$ & $\mathbf{2}$ & $\mathbf{3}$ & $\mathbf{4}$ & $\mathbf{5}$ & 30 \\
\hline I & 26 & 4 & 0 & 0 & 0 & 0 & $(100 \%)$ \\
& $(86.66 \%)$ & $(13.33 \%)$ & $(0 \%)$ & $(0 \%)$ & $(0 \%)$ & $(0 \%)$ & 22 \\
\hline II & 2 & 10 & 0 & 1 & 9 & 0 & $(100 \%)$ \\
& $(9.09 \%)$ & $(45.54 \%)$ & $(0 \%)$ & $(4.54 \%)$ & $(40.90 \%)$ & $(0 \%)$ & 21 \\
& 4 & 13 & 0 & 0 & 3 & 1 & $(100 \%)$ \\
\hline
\end{tabular}

I- control; II- polypropylene; III- latex coated polypropylene

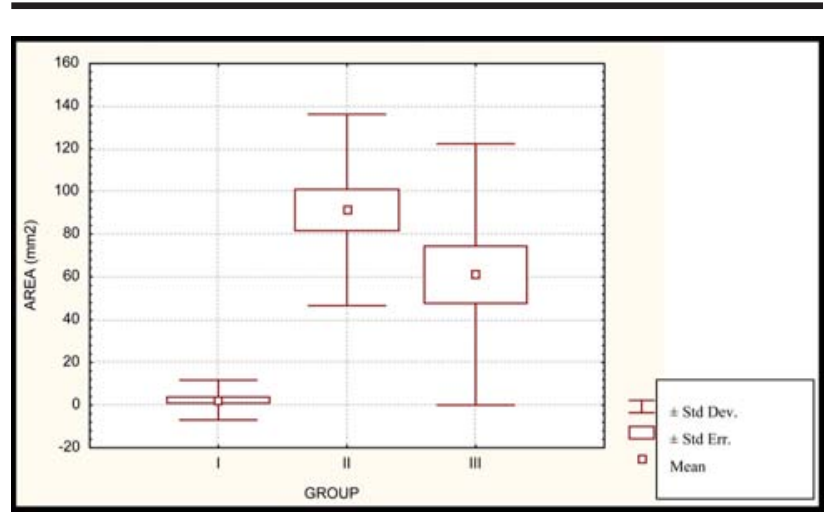

FIGURE 11 - Animals distribution in relation to the adhesion area according to the group

\section{Discussion}

The option for euthanasia after 45 days of surgery was adequate because tissue repair is an inflammatory reaction that occurs due to vascular permeability alterations and consequent extrusion of substances and cells to interstice, leading to fibrin deposit. Surgery trauma and strange body reaction inhibit plasminogen activator activity, what causes fibrinolysis reduction, resulting in an increase in the deposition of fibrin ${ }^{14}$. This fibrin matrix gradually organizes in a fibrous adhesion in approximately 5 days but, after that, the adhesions extension gradually diminishes in approximately $30 \%{ }^{14}$. In rats, the intra-abdominal adhesions are formed 24 hours after surgery, and after 7 days no other new adhesion is formed ${ }^{10}$. As we used rats of the same strain and sex, receiving the same care, the possibly different variables were the weight and the prosthesis used in each group. Since there was no difference in pre-surgery weights $(p>0.05)$, the only variable was the kind of prosthesis used. Therefore, the differences found must be mainly attributed to it, or eventually to the hazard. 
In order to avoid adhesions, we can use liquids in peritoneal cavity or materials coating the prostheseis ${ }^{14,21,22,23}$. We decided for the use of a coating in the polypropylene prosthesis because the function of the adhesions is still controversial. Feng ${ }^{24}$ demonstrated that the adhesions beneficially affect anastomosis, increasing its mechanical resistance in the initial phase of tissue repair, concluding that the adhesions are physiological and play an important role in the organism, however, if formed in excess or involving the abdominal wall, they can be damaging. By this point of view, intraperiotoneal liquids infusion to avoid adhesions could endanger anastomosis. Nevertheless, Ertuk ${ }^{25}$ did not confirm this hypothesis showing that the application of hyaluronic acid-carboxymetilcellulose in ischemic anastomoses diminishes adhesion formation, without compromising its integrity. Therefore, if the literature is controversial in relation to the protector or non-protector role of the adhesions over the anastomoses, it is consensual that its excessive formation and principally the ones that involve the abdominal wall can be damaging, and these are the ones we intend to reduce with prostheses coating. Many experimental studies evaluate the adhesions using a grading system $^{12,18,19}$ that, apart from being subjective, may not be advantageous in clinical practice. Therefore, this quantification, concomitant with two other forms of studying adhesions in an objective way (calculation of the adhesion area and observation of complications and deaths), is a more careful proceeding. By the clinical point of view, this last analysis is the most important in patients with peritoneostomies, since the complications as fistulas, eviscerations and obstructions are potentially lethal, and these patients are generally in a serious health condition. Calculating the adhesion area becomes important because we calculate the adhesions that attack the abdominal wall, which, as discussed before, are the ones we want to avoid. In the study of Dinsmore ${ }^{12}$ they used a digital camera and a computer program calculated the areas. The use of a planimeter in our study was an adaptation, since it was the only resource available in our Institution. Nevertheless, although not described in the original study, we observed that if the resection piece was totally immerse in the Indian blue solution, the skin could not be totally repaired and the ink could penetrate and stain under the adhesions that would be removed, harming though the delimitation of the light-colored area produced by the adhesions removal. The survival of all rats in control group must be due to the fact of not using prostheses and not resecting the tissues. As there was fewer adhesion formations in control group than in the two experimental groups, under any analysis, this is the one that most approximates to the physiological state. The two analyzed materials leaded to excessive adhesion formation, remaining thus to analyze if there is any difference between them. As the latex coating leaded to fewer adhesion formations, according to the evaluation by a grading system, if this study had only used this methodology, we could have concluded that latex coating is effective in reducing adhesions. However, the adhesion area was not different between groups I and II. Moreover, the post-surgery evolution proved that latex coating did not avoid the early complications such as fistula, obstruction and evisceration, which leaded to the death of some animals. There was no difference in weight after 45 days either, indicating that the difference in adhesions formation does not interfere with the general state of the animals. So, the diminishment of adhesions formation by the use of latex coating, evaluated by the grading method after 45 days of surgery, in our experiment, was not advantageous by the clinical point of view. Other kinds of studies are necessary to know if this diminishment could avoid late complications like pain and late sub-occlusions and, mostly, clinical epidemiological studies to confirm these effects in the human being.

\section{Conclusion}

The coating of the prosthesis by latex leads to fewer adhesion formations, but does not diminish the early serious complications.

\section{References}

1. Rahal F. Análise crítica dos materiais usados no reforço cirúrgico. In: Silva AL. Hérnias. São Paulo: Roca, 1992. p.1143-7.

2. Di Bello JN Jr, Moore, JH Jr. Slinding myofascial flap of the rectus abdominus muscles for the closure of recurrent ventral hernias. Plast Reconstr Surg. 1996;98(3):464-9.

3. Silva AL. Uso do saco herniário no reforço da hernioplastia inguinal. Rev Col Bras Cir. 1995;3:153-4.

4. Usher FC, Gannon JP. Marlex mesh, a new plastic mesh for replacing tissue defects I: experimental studies. AMA Arch Surg. 1959;78(1):131-7.

5. Usher FC. A new plastic prosthesis for repairing tissue defects of the chest and abdominal wall. Am J Surg. 1959;97(5):629-33.

6. Greenstein SM, Murphy TF, Rush BF Jr, Alexander H. Evaluation of polylactic acid-carbon mesh for repair of ventral herniorrhaphy. Am J Surg. 1986;151(5):635-9.

7. Larson GM, Harrower HW. Plastic mesh repair of incisional hernias. Am J Surg. 1978;135(4):559-63.

8. Ludington LG, Woodward ER. Use of teflon mesh in the repair of musculofascial defects. Surgery. 1959;46(2):364-73.

9. Read RC. Bilaterality and the prosthetic repair of large recurrent inguinal-hernias. Am J Surg. 1979;138(6):788-93.

10. Sugarbaker PH. Peritoneal approach to prosthetic mesh repair of paraostomy hernias. Ann Surg. 1985;201(3):344-6.

11. Baptista ML, Bonsack ME, Delaney JP. Seprafilm reduces adhesions to polypropylene mesh. Surgery. 2000;128(1):86-92.

12. Dinsmore RC, Calton WC Jr, Harvey SB, Blaney MW. Prevention of adhesions to polypropylene mesh in a traumatized bowel model. J Am Coll Surg. 2000;191(2):131-6.

13. Jenkins SD, Klamer TW, Parteka JJ, Condon RE. A comparison of prosthetic materials used to repair abdominal wall defects. Surgery. 1983;94(2):392-8.

14. van'T Riet M, de Vos van Steenwijk PJ, Bonthuis F, Marquet RL, Steyerberg EW, Jeekel J, Bonjer HJ. Prevention of adhesion to prosthetic mesh: comparison 
of different barriers using an incisional hernia model. Ann Surg. 2003;237(1):123-8.

15. Holmdahl L. The role of fibrinolysis in adhesions formation. Eur J Surg. 1997;(577):24-31.

16. Mrué F. Substituição do esôfago cervical por prótese biossintética de látex: estudo experimental em cães [Dissertação Mestrado]. Universidade de São PauloFaculdade de Medicina de Ribeirão Preto; 1996.

17. Frade MAC, Valverde RV, de Assis RVC, Coutinho-Netto J, Foss NT. Chronic phlebopathic cutaneous ulcer: a therapeutic proposal. Int J Dermatol. 2001;40(3):238-40.

18. Oncel M, Remzi FH, Senagore AJ, Connor JT, Fazio VW. Comparison of a novel liquid (Adcon- $\mathrm{P}^{\circledR}$ ) and sodium hyaluronate and carboxymethylcellulose membrane $\left(\right.$ Seprafilm $\left.^{\mathrm{TM}}\right)$ in postsurgical adhesion formation in a murine model. Dis Colon Rectum. 2003;46(2):187-91.

19. D’Oliveira DMR, Nigro AJT, Fagundes DJ, Novo NF, Juliano Y, Pimenta ALP. Estudo morfológico de aderências peritoneais induzidas pela rifampicina, em ratos. Acta Cir Bras. 2001;16:103-9.

20. Diogo FilhoA, Lazarini BCM, Silva GJ, Vieiro Jr FV, Gomes HL. Avaliação das aderências pós-operatórias em ratos submetidos a peritoniostomias com tela de polipropileno associada a nitrofurazona. Arq Gastroenterol. 2004;41:245-9.
21. Jackson EK. Intraperitoneal administration of adenosine inhibits formation of adbominal adhesions. Dis Colon Rectum. 2004;47(8):1390-6.

22. Bakkum EA, Dalmeijer RAJ, Verdel MJC, Hermans J, van Blitterswijk CA, Trimbos JB. Quantitative analysis of the inflammatory reaction surrounding sutures commonly used in operative procedures and the relation to postsurgical adhesion formation. Biomaterials. 1995;16(17):1283-9.

23. Smaniotto B, Biondo-Simões MLP, Artigas GV, Gomes da Silva AP, Collaço LM, Ramasco GV. Effect of Streptokinase in the prevention of intra-abdominal adhesion in the rat. Acta Cir Bras. 1997;12:240-5.

24. Feng CW, Ayrizono MLS, Fagundes JJ, Coy CSR, Góes JRN, Leonardi LS. Estudos biomecânicos da ação de aderências sobre anastomose cólica. Trabalho experimental em ratos. Acta Cir Bras. 2003;18:0-0.

25. Erturk S, Yuceyar S, Temiz M, Ekci B, Sakoglu N, Balci H, Dirican A, Cengiz A, Saner H. Effects of hyaluronic acidcarboxymethylcellulose antiadhesion barrier on ischemic colonic anastomosis: an experimental study. Dis Colon Rectum. 2003:46(4)529-34.

\section{Correspondence:}

Renato Hugues Atique Claudio Av. Nicomedes Alves dos Santos, 116 38.402-078 Uberlândia-MG Brazil renatoatique@hotmail.com
Conflict of interest: none Financial source: Laboratory of Surgery Techniques Federal University of Uberlândia

Received: July 08, 2006

Review: August 16, 2006 Accepted: September 20, 2006

\section{How to cite this article:}

Claudio RHA, Diogo Filho A, Mamede Filho DO. Peritoneostomy with latex coated polypropylene: experimental study in rats. Acta Cir Bras. [serial on the Internet] 2006 Nov-Dec;21(6). Available from URL: http://www.scielo.br/acb. 